\title{
Teacher Preparation and the Tenants of Accountability
}

\author{
Leslie Jones ${ }^{1}$, Gregg Stall ${ }^{1}$, Gary Rosenthal ${ }^{1}$, Jessica Fanguy Cortez ${ }^{1}$, Angelle Hebert ${ }^{1}$, \\ Ruth Ray Jackson ${ }^{2}$, Thea Williams-Black ${ }^{3}$ \\ ${ }^{1}$ College of Education, Nicholls State University, Thibodaux, USA \\ ${ }^{2}$ College of Education, Langston University, Langston, USA \\ ${ }^{3}$ College of Education, Jackson State University, Jackson, USA \\ Email: leslie.jones@nicholls.edu
}

Received 21 July 2015; accepted 7 December 2015; published 10 December 2015

Copyright (C) 2015 by authors and Scientific Research Publishing Inc.

This work is licensed under the Creative Commons Attribution International License (CC BY).

http://creativecommons.org/licenses/by/4.0/

(c) (i) Open Access

\section{Abstract}

There is an obvious interrelationship between $\mathrm{K}-12$ student performances and the preparation of teachers in Teacher Education Programs in Higher Education. As accountability increases in K-12 educational systems for students and teachers, accountability increases in Teacher Preparation Programs. There are different methods for evaluating the effectiveness of Teacher Preparation Programs; and recent evaluation methods have focused on the performances of the $\mathrm{K}-12$ students through value-added models. There are proponent and opponents of using value-added models. However, there is much agreement on the need to make improvements to Teacher Preparation Programs. A Task Force was formed in $\mathbf{2 0 1 2}$ called the Network for Transforming Educator Preparation (NTEP). The Task Force was formed by the Council of Chief State School Officers (CCSSO). Licensure, Program Approval, and Data Collection, Analysis and Reporting are among the key areas addressed by the Tasks Force:

http://www.ccsso.org/Resources/Programs/Network for Transforming Educator Preparation ( NTEP).html. These are the similar areas addressed through accreditation processes for Teacher Preparation Programs. In this article, the challenges of accountability with a focus on accreditation are addressed. A review of teacher accreditation and six elements for improving teacher preparation are also discussed.

\section{Keywords}

Teacher Preparation, Higher Education, Accountability

\section{Introduction}

There are frequently many initiatives and programs implemented in K-12 schools to target school improvement

How to cite this paper: Jones, L., Stall, G., Rosenthal, G., Cortez, J. F., Hebert, A., Jackson, R. R., \& Williams-Black, T. (2015). Teacher Preparation and the Tenants of Accountability. Creative Education, 6, 2256-2262. 
focusing specifically on student achievement. Schmoker (2011) suggests that there are three simple elements essential for school improvement: reasonable coherent curriculum, sound lessons, and purposeful reading and writing in all disciplines. Schmoker (2011) defines coherent curriculum as the information that is taught, sound lessons are defined as how information is taught, and the purposeful reading and writing are authentic literacy; interestingly, Schmoker (2011) notes that the three essentials are rarely implemented.

At the heart of school improvement, specifically student learning and achievement, are teacher preparation. The historical challenge of the under-performing students, the implementation and the debate surrounding the implementation of common core with the smarter balance and Partnership for Assessment for Readiness for College and Careers (PARCC) as assessments, emphasis on value-added teacher accountability models, and the recent report from the National Council on Teacher Quality (NCTQ) all contribute to the heightened emphasis on high quality teacher preparation programs (http://www.nctq).

Schmoker (2011) suggested in Focus that student learning depends on what teacher the student has. Similar assertions were made by other theorists; however, others (e.g. the Coleman Report) expressed an alternative opinion. The findings of the Coleman Report indicated that schools made slight, if any, contributions to student achievement. A number of variables have been correlated with student achievement since the Coleman Report in 1966 (Coleman, 1966). Hattie (2012) completed meta-analyses documenting 138 effective sizes and influences across areas related to student achievement. He suggests that there are six areas that contribute to learning, teaching and learning approaches, curricula, teacher, school, home, and the student.

In this article, the issue of effective teaching is addressed from the perspective of how students are prepared in teacher preparation programs. First, a brief overview of the challenges of accountability is presented beginning with the Elementary and Secondary Education Act (ESEA). Accountability measures for teacher education preparation programs are included with a specific look at accrediting agencies. The Six Essential Elements for Improving Teacher Preparation published in Education Week are also discussed (Marshall, 2013).

\section{Challenges of Accountability with a Look at Accreditation}

The Elementary and Secondary Education Act (ESEA) was the first government regulated attempt to play a role in the achievement of K-12 students. Many local and state governments resisted the national intervention before ESEA. One of the goals of ESEA, which is reinforced in the reauthorization of $N C L B$, is to address equality in education. According to a report in Education Sector by Chubb \& Clark (2013) the poorer students of the nation did not benefit from the initial implementation of ESEA. While, there have been improvements in performance of low achieving students, it is unclear the role that NCLB has played in the gains. Furthermore, many states have received waivers from NCLB.

It has been challenging to compare progress from state to state prior to $N C L B$ because of the different state tests. The National Assessment of Education Progress (NAEP) has been the de factonational measure for the past decade. Smarter Balance and Partnership for Assessment for Readiness for College and Careers (PARCC) are more recent assessments that will soon be implemented with the Common Core. Many states have adopted the Common Core Standards in an effort to provide a consistent, clear understanding of what students are expected to learn. States are beginning to opt out of implementing Common Core Standards. It is noteworthy that there is some national resistance to common core adoption and implementation (http://www.corestandards.org) from educators and other entities.

Embedded in NCLB and state accountability plans is teacher accountability. Teacher preparation is also at the heart of teacher accountability. Previously, we stated that teacher preparation is at the heart of school improvement. Most states require universities and other preparation providers to acquire accreditation. The Council for Accreditation of Educator Preparation (CAEP) is the newest accrediting entity. It resulted from the merger of the Teacher Education Accreditation Council (TEAC) and the National Council for Accreditation of Teacher Education (NCATE). CAEP will serve as the accrediting agency for Teacher Education Preparation replacing NCATE and TEAC.

The transition to CAEP will be completed in 2016. Many programs will maintain accreditations through NCATE and TEAC until the transition is complete. One of the goals of CAEP is to improve teacher preparation programs so candidates are better prepared to teach and thus to ultimately advance K-12 learning. CAEP holds programs accountable for candidates demonstrating knowledge, skills, and professional dispositions for effective work in schools; data-driven decisions linked to candidates and programs, and resources and practices that sup- 
port candidate learning (http://www.ncate.org).

NCATE is one of the oldest specialized accrediting entities. Accreditation has a history of more than one hundred years. A layer above the specialized accreditation for Colleges is regional accreditation for institutions. In the United States, there are six geographical regions. According to a report from the Senate Committee on Health, Education, Labor, and Pensions (www.help.senate.gov), accreditation serves two purposes, the first is institutional. The external peer-review accreditation process helps provide constructive insight and feedback to academic programs. The second purpose is a federal and public purpose base. The federal government and public view accreditation processes act as quality assurance measures.

The senate committee report referenced above suggested there are problems with accreditation to address. They include the problem that: accreditation has not always produced or improved educational quality, that accreditation can inhibit innovation and competition, that federal recognition of accreditation can be political and bureaucratic and that accreditation can be costly, burdensome and inefficient.

\section{Specific Review of Teacher Accreditation}

NCATE was established in 1954 to replace the American Association of Colleges of Teacher Education (AACTE) as the accrediting entity. According to www.ncate.org, the mission of NCATE is to help prepare high quality teachers, specialists, and administrators. The system for accreditation is performance-based, and educational entities are required to demonstrate mastery of six standards.

Several experts have weighed in on the key components of effective teacher preparation. Arthur Wise, President of NCATE suggested that the key to effective teacher preparation is that members of the profession insist on high standards of preparation. Wise suggests that teaching as a profession is in a transitory period similar to the period medicine experienced between 1890 and 1910. Physicians demanded at state levels that doctors be graduates of nationally accredited schools. Educators are now imposing similar demands (Edutopia, 2013).

In 2006, Darling-Hammond; Professor of Education at Stanford's School of Education noted that teacher effectiveness is linked to teacher preparation/knowledge of teaching and learning, subject matter knowledge, experience, and teacher licensure, and that high quality teacher preparation is important. Darling-Hammond (2006) also suggests that the teacher preparation program is critical to fostering effective teachers. The courses and field experiences are organized around what good teaching is. It is essential also for candidates to work with expert master teachers who provide ideas about student learning and assessments. Feistritzer (Edutopia, 2013) made a similar assertion about the importance of real-life experiences. She is the president for the National Center for Education Information. Feistritzer stated that top-of-the-line issue for prospective teachers is to get into classroom settings early with mentor teachers (Edutopia, 2013).

Interestingly, one of the six performance standards of NCATE is field experiences and clinical practice. Field experiences and clinical practice is Standard 3. NCATE defines the standard as follows: "The unit and its school partners design, implement, and evaluate field experiences and clinical practices so that teacher candidates and other school professionals develop and demonstrate the knowledge, skills, and professional dispositions necessary to help all students learn" (http://www.ncate.org).

Field experiences and clinical practices require program providers to collaborate with K-12 schools. As previously referenced from experts, teacher candidates should engage in a variety of experiences beginning very early. CAEP has proposed three standards; and one of those is Clinical Partnerships and Practice. The descriptor of the Clinical Partnerships and Practice standard posted at http://edsource.org/wp-content/uploadscommrpt.pdf is "the provider ensures that effective partnerships and high quality clinical practice are central to preparation so that candidates develop knowledge, skills, and professional dispositions necessary to demonstrate positive impact on all P-12 students' learning and development.” In 2003, Louisiana Teacher Preparation Programs engaged in a redesign initiative. One of the recommendations of the initiative is for candidates to complete one hundred and eighty hours of field experiences prior to student teaching.

Student teaching is similar to an Internship. Candidates work alongside a mentor teacher for a semester or two engaging in all of the duties of a teacher. Planning and implementing lessons are pertinent components of the experience; however, candidates also attend professional development and other meetings, work with parents, work with other colleagues and experience the totality of the day-to-day work of a teacher. The expectations for the candidates are to have satisfactory ratings as determined by the pertinent university/school district faculty and staff. There are variations to the length of student teaching experiences; however, student teaching is at 
minimum one semester.

An entry/beginning level of field experiences for teacher candidates is observations. There are obvious benefits of classroom observations. According to Dr. Bilash, observations are an important part of learning how to teach. The huge benefit is that observations are "glimpses" at real life teaching. Experienced teachers can use observations as a form of professional development (Edutopia, 2013).

The "capstone" level of field experiences is for prospective teachers to plan and teach lessons for K-12 students in schools. Prior to prospective teachers teaching as a part of their field experiences, there are various experiences like one-one tutoring, small group tutoring, and teaching small segments of lessons they engage in before teaching a full lesson. It is important for prospective teachers to experience a full range of the field experiences throughout preparation programs.

The importance of practical experiences for perspective teachers have been noted again and again by experts; accrediting entities and practicing teachers have recognized the importance of field experiences for perspective teachers and suggested that practicing teachers gain as much from the experiences as the teachers in training. Another positive effect of quality field experiences is that learning for K-12 students in the classroom is improved. This provides a direct correlation between/among accountability in K-12 and accountability for teacher education program providers (Edutopia, 2013).

The National Council on Teacher Quality (NCTQ) advocates for reforms in policies at all levels to increase teacher effectiveness. According to www.nctg, NCTQ was founded to provide a national voice to existing teacher organizations and to "build the case for comprehensive reform agenda that would challenge the current structure and relation of the profession."

NCTQ started a national campaign to evaluate teacher preparation programs. In 2012, NCTQ released a report rating over two thousand programs. The ratings were assigned on a four-point scale, and the majority of the programs received two points. Over one-hundred programs received the rating "consumer alert" which was below the rating indicative of a program providing weak preparation (http://www.nctq).

In Louisiana, reform and accountability for teachers and principals have recently been linked with the passage of Act 54. Fifty-percent of teacher evaluations are now based on the learning of students measured by the valueadded model or other student growth measures (http://www.doe.la.us). Value-added is becoming popular in many states.

\section{The Six Essential Elements for Improving Teacher Preparation}

In an article released in Education Week, Marshall (2013) discussed The Six Essential Elements for Improving Teacher Preparation. The elements underlined and discussed.

Be Practical: The value of theory should not be minimized; however, the value of practice is critical to most if not all professionals particularly in professional preparation programs. As previously discussed from the perspective of experts, the value of classroom experiences for prospective teachers in preparation programs is essential. The hands-on experiences give prospective teachers opportunities to engage in activities pertinent to the job.

Professionals are often aware of best practices but do not implement them. In the Knowing Doing Gap, Pfeffer and Sutton (2000) discuss the challenges of implementing known best practices. They argue that training, management consulting, business research, books and articles produce little or no implementation of known best practices. This concept is true of all professions; participation in professional development opportunities in education does not strongly correlate with implementation of acquired knowledge.

Pfeffer and Sutton (2000) note several reasons why known best practices are not implemented:

- Talk is substituted for action;

- Memory is substituted for thinking, that is—past practices are applied to current problems;

- Fear prevents acting on knowledge;

- Measurement is used to obstruct judgment, that is, flawed measures are repeatedly used; and

- Enemies develop in work places as a result of competition.

Each barrier to change is discussed thoroughly by Pfeffer and Sutton. In brief, the first barrier is when talk is substituted for action-Pfeffer and Sutton cited several ways in which talk is substituted for action; often, it happens because individuals make decisions which are often mistaken for action. The change will not occur until decisions are implemented. Like making decision; presentations of information, preparation of documents, and the use of mission statements can all be substitutes for action. 
The following are indicators that talk is being substituted for action:

- No follow-up is done;

- People forget that making a decision does not imply changes;

- Planning, meetings, and report writing become defined as "action" that is valuable on its own;

- People believe that because they have said it and it is in the mission, then it must be occurring;

- People are evaluated on how smart they sound rather than their actions;

- Talking a lot is mistaken for doing a lot;

- Complex language, ideas, processes, and structures are thought to be better than simplicity;

- There is a belief that managers are people who talk and others do; and

- Internal status comes from talking a lot, interrupting and being critical of others' ideas.

Obviously, "knowing what to do is not enough." The field experiences give candidates an opportunity to implement best practices. The second of the six elements is aligned closely with the first.

Full Year Experience: The mandate of the full year of experience is the maximization of practical experiences. The levels of field experiences were previously discussed beginning with observations. The notion that field experiences occur throughout teacher training programs was also addressed. The full year of teaching is the optimum level of field experience. Having multiple mentors is the "b" component of the second element. Prospective teacher candidates can acquire a repertoire of knowledge from multiple perspectives. This adds to the candidate's diversity of experiences — which leads to a more thorough preparation (Edutopia, 2013).

Alignment of school training and teaching experience: Essential element three is to align the type of school training to the teaching experience. Candidates should prepare for the grade level, differences in learning levels of students, demographic clientele that will be taught, geographic area (urban, rural, and suburban) etc. The requirements for optimal NCATE field experiences were discussed previously.

Institutions which are NCATE accredited require candidates to have field experiences in diverse areas. Candidates are required to have experiences in multiple kinds of settings (urban, rural, or suburban). Candidates are required to work with disadvantaged populations and candidates must demonstrate the abilities to prepare instruction to meet the diverse needs of different kinds of learners (http://www.ncate.org).

In this era, it is crucial to work with students with diverse needs because so many of the students have diverse needs. One of the factors embedded in accountability is improving the performance of disadvantaged students and students of minority populations. It is noteworthy that information released from Educational Sector indicates that African American students are one and half grade levels below European white students (Chubb \& Clark, 2013).

In many introductory courses to education, observations occur across multiple grade levels. When I completed undergraduate studies in education, I conducted multiple observations in elementary, middle and high school. I was preparing for high school certification; however, it was advantageous to experience the different grade levels.

Build in failure and resilience: Based on practical experience, Marshall (2013) suggests that it is necessary for aspiring teachers to fail repeatedly in teacher-in-training "while there are still supports in place.” Build in failure and resilience is the fourth of the six elements. Oliva \& Pawlass (2008) suggest that teachers must develop a "sixth sense" when working with students. The development of the sixth sense to an extent signals a need to experience multiple tries with the lack of success which aligns with the need for resilience. The development of such strength implies that the teacher candidate must learn to try-again multiple times after experiencing a setback or failure; this aligns with a teacher's need for resilience.

The philosophy proposed by Marshall (2013) may appear to include contradictory concepts embedded in publications like Failure is Not an Option and The Dance of Change (Senge et al., 1999); actually, the philosophy is not inconsistent. One of the premises noted in Failure is Not an Option (Blankstien, 2010) is that change is necessary and change is difficult. From the perspective of a teacher candidate, it may well be the need to make constant changes that may be the most difficult.

Observations in a variety of schools: Element five proposed by Marshall (2013) is that teacher candidates must make observations in a variety of schools. Concepts pertinent to element five were discussed in elements one, two, and three. Practical experiences in a variety of schools with multiple mentors are invaluable. Most educators will acknowledge that schools may have similar characteristics, demographics, etc.; however, schools often have very unique features which so that aspiring teachers to experience multiple environments.

Emphasize humility: Marshall (2013) discusses the need for emphasizing humility as element six. In Good to 
Great, Collins (2001) notes that the "enemy of great is good.” There are so many practical implications of this concept; however, this implies that all professionals should have moving targets—as goals and objectives are met, others must be developed. Educators must always carry themselves with humility; there are always areas in which they can improve.

NCATE noted that critics questioned the role of teacher preparation as a factor in teacher effectiveness. NCATE also notes that high quality teacher preparation is important and there are five key principles to superior preparation programs that are research-based. They are:

- Teacher preparation helps candidates develop the knowledge and skill they need in the classroom;

- Well prepared teachers are more likely to remain in teaching;

- Well prepared teachers produce higher student achievement;

- Leading industrialized nations invest heavily in pre-service teacher preparation; and

- NCATE makes a difference in teacher preparation.

Several entities have noted the importance of teacher preparation with empirical evidence to support the premise. The entities include the National Academy of Education, the American Educational Research Association, the National Research Council, the Center for the Study of Teaching and Policy, and the Education Commission of the States; there a many others.

The National Academy of Education completed a bibliography of research supporting the need for both knowledge based and skill based teacher preparation. Anecdotal information from high school students indicates the necessity of teaching pedagogical skills coupled with content knowledge.

\section{Conclusion}

There are various approaches and perspectives available to define effective teaching. In this article, effective teaching is presented from the vantage point of tenants of preparation programs. A standards-based approach is inclusive with a discussion of accreditation. Within the framework of accreditation, there is a direct link to accountability.

Accountability is obviously multi-dimensional; there is accountability for K-12 entities, higher education and colleges of education and individual accountability of all professionals.

Student achievement is a critical variable for measurements and defining accountability, and the effectiveness of teacher preparation programs has been directly correlated with student achievement. Accountability for higher education is also defined by teacher preparation. Schmoker (2011) is cited earlier regarding the importance of student achievement and the role that teachers play in student achievement. Siconne (2012) notes that teachers are one of two critical variables linked to student achievement; the other is school leadership-principal preparation is equally important and directly aligned to teacher preparation.

There are no clear indicators that the nation is truly focusing on accountability since (as noted previously); states are receiving waivers from NCLB. However, the heightened attention to K-12 student underperformance indicates the importance of accountability, student achievement, and teacher preparation.

\section{References}

Blankstein, A. M. (2010). Failure Is Not an Option. 6 Principles of Making Student Success. The ONLY Option. California: Corwin.

Chubb, J., \& Clark, C. (2013). The New State Achievement Gap: How Federal Waivers Could Make It Worst Or Better. Educational Sector: Connecticut. Creative Commons.

Coleman, J., Campbell, E., Hobson, C., McPartland, J., Mood, A., Weinfield, F., \& York, R. (1966). Equality of Educational Opportunity. Washington: US Department of Education and Welfare. Publication of National Center for Educational Statistics. Superintendent Documents Catalog No. FS 5.238.38001.

Collins, J. (2001). Good to Great. New York: Harper Collins Publishers.

Darling-Hammond, L. (2006). Powerful Teacher Education: Lessons from Exemplary Programs. San Francisco: John Wiley and Sons, Inc.

Edutopia Staff (2013) Key Components of Effective Teacher Preparation: The Experts Speak. EDUTOPIA. WHAT WORKS IN EDUCATION. The George Lucas Education Foundation.

Hattie, J. (2012). Visible Learning for Teachers. New York: Routledge.

Marshall, L. (2013). Six Essential Elements for Improving Teacher Prep. Education Week. 
Oliva, P. F., \& Pawlass, G. E. (2008). Supervision for Today’s School’s. New Jersey: Wiley.

Pfeffer, J., \& Sutton, R. I. (2000). The Knowing Doing Gap. Massachusetts: Harvard Business School of Publishing.

Retrieved from Common Core State Standards Initiative. http://www.corestandards.org

Retrieved from Council of Chief State School Officers.

http://www.ccsso.org/Resources/Programs/Network for Transforming Educator Preparation (NTEP).html

Retrieved from http://edsource.org/wp-content/uploadscommrpt.pdf; CAEP Accreditation Standards and Evidence: Aspirations for Educator Preparation.

Retrieved from Louisiana State Department of Education. http://www.doe.la.us

Retrieved from National Council of Teacher Quality. http://www.nctq.org

Retrieved from That National Council of Teacher Accreditation. http://www.ncate.org

Schmoker, M. (2011). Focus: Elevating the Essentials to Radically Improve Student Learning. Virginia: Association of Curriculum.

Senge, P., Kleiner, A., Roberts, C., Ross, R., Roth, G., \& Smith, B. (1999). A Fifth Discipline: The Dance of Change: The Challenges of Sustaining Momentum in Learning Organizations. New York: Currency Doubleday.

Siconne, F. (2012). Essential Skills for Effective School Leadership. Boston: Pearson Education. 